Synt hesi s of a bow - type dodecavanadate by the coupl ing react i on of al koxohexavanadate and di scovery of a chi ral oct adecavanadate

\begin{tabular}{|l|l|}
\hline 著者 & $\begin{array}{l}\text { Domae Kyosuke, Uchi mur a Dai suke, Koyama Yuuki, } \\
\text { I nami Shi nnosuke, Hayashi Yoshi hi to, I sobe } \\
\text { Ki yoshi, Kaneda H royuki, Shi moda Tat suya }\end{array}$ \\
\hline $\begin{array}{l}\text { j our nal or } \\
\text { publ i cat i on t itl e }\end{array}$ & Pure and Appl i ed Chemi st ry \\
\hline vol une & 81 \\
\hline number & 7 \\
\hline page r ange & $1323-1330$ \\
\hline year & 2009- 01- 01 \\
\hline URL & ht t p: //hdl . handl e. net /2297/19143 \\
\hline
\end{tabular}


Pure Appl. Chem., Vol. 81, No. 7, pp. 1323-1330, 2009.

doi:10.1351/PAC-CON-08-08-25

(c) 2009 IUPAC, Publication date (Web): 29 June 2009

\title{
Synthesis of a bowl-type dodecavanadate by the coupling reaction of alkoxohexavanadate and discovery of a chiral octadecavanadate*
}

\author{
Kyosuke Domae ${ }^{1}$, Daisuke Uchimura ${ }^{1}$, Yuuki Koyama ${ }^{1}$, \\ Shinnosuke Inami ${ }^{1}$, Yoshihito Hayashi ${ }^{1, \ddagger}$, Kiyoshi Isobe ${ }^{1}$, \\ Hiroyuki Kameda ${ }^{2}$, and Tatsuya Shimoda ${ }^{2,3}$ \\ ${ }^{1}$ Department of Chemistry, Graduate School of Natural Science, Kanazawa \\ University, Kakuma, Kanazawa, 920-1192, Japan; ${ }^{2} J S T$, ERATO, Shimoda \\ Nanoliquid Process Project, 2-5-3 Asahidai, Nomi-shi, Ishikawa 923-1211, Japan; \\ ${ }^{3}$ School of Materials Science, Japan Advanced Institute of Science and Technology \\ (JAIST), 1-1 Asahidai, Nomi, Ishikawa 923-1292, Japan
}

\begin{abstract}
A new route to an alkoxohexavanadate species leads to the isolation of a bowl-type dodecavanadate without a guest molecule in the cavity. The $1 \mathrm{D}$ tetravanadate, $\left[\mathrm{V}_{4} \mathrm{O}_{11}\right]^{2-}$, is a good precursor for the alkoxohexavanadate, $\left[\mathrm{V}_{6} \mathrm{O}_{13}\left(\mathrm{OCH}_{3}\right)_{6}\right]^{2-}$, which is then utilized for the $[\mathrm{V} 6+\mathrm{V} 6]$ coupling reaction to form the dodecavanadate, $\left[\mathrm{V}_{12} \mathrm{O}_{42}\right]^{4-}$, with a capped dichloromethane molecule at the cavity entrance. We also obtained structural information on a newly discovered octadecavanadate, $\left[\mathrm{V}_{18} \mathrm{O}_{46}\left(\mathrm{NO}_{3}\right)\right]^{5-}$, in both the solid and solution states through extended X-ray absorption fine structure (EXAFS) studies. The existence of the chiral inorganic species in acetonitrile with double-stranded V8 chains was confirmed through EXAFS oscillations.
\end{abstract}

Keywords: hexavanadates; alkoxovanadates; polyoxoalkoxovanadates; dodecavanadates; octadecavanadates; chiral polyoxovanadates.

\section{INTRODUCTION}

The sequential condensation of vanadate species in solution provides a rich chemistry of polyoxovanadates. In nonaqueous media, reduced systems either in condensed structures, such as tridecavanadates [1], or in spherical structures, such as template-incorporated octadecavanadates [2], have been synthesized. Collision reactions between these species either serve to build them up or to break them apart through equilibrium. A balance between these growth processes leads to a distribution of the species. In aqueous solution, the growth is sequential, beginning with pyrovanadates, condensing to metavanadates, and finally around neutral $\mathrm{pH}$, decavanadates are formed [3]. The higher acidification becomes, the larger the polyoxovanadate grows, and the build-up of negative charges increases. Its growth stalls once it becomes a decavanadate in aqueous solution.

These condensations may include the existence of unrealized intermediate species such as a hexavanadate anion. Hexavanadate and decavanadate anions share the same basic structural arrangement of

\footnotetext{
*Paper based on a presentation at the $6^{\text {th }}$ International Symposium on Chemistry and Biological Chemistry of Vanadium, 17-19 July 2008, Lisbon, Portugal. Other presentations are published in this issue, pp. 1187-1330.

¥Corresponding author
} 
their constituent units. Each structure begins with six $\mathrm{O}$ atoms around a $\mathrm{V}^{\mathrm{V}}$ center, in the shape of a regular $\mathrm{VO}_{6}$ octahedron. The octahedrons are then stacked into a larger octahedron. Each of the six $\mathrm{VO}_{6}$ units are linked through edge sharing to give an even larger octahedral structure, $\left[\mathrm{V}_{6} \mathrm{O}_{19}\right]^{8-}$, also known as a hexametalate structure. Hexametalate anion, a symmetrical octahedral closest-packed unit, is a fundamental building block in polyoxometalate chemistry of $\mathrm{Mo}, \mathrm{W}$, and $\mathrm{Nb}$. Decavanadate anion is essentially a fused dimer of the hexametalate. It is plausible that the hexavanadate anion, despite being unnoticed until recently, may be a short-lived intermediate species in the course of the formation of the decavanadate anion. In another view, the core of the hexametalate may be regarded as the smallest spherical polyoxovanadate that includes an oxo anion at the center as shown in Fig. 1. In polyoxovanadate species, it should be very reactive due to its high negative charges which, due to repulsion, move toward an open framework by splitting the $\mathrm{M}-\mathrm{O}$ bonds. The instability of hexavanadate anion may make the species a good precursor for the synthesis of new types of polyoxovanadates. In this paper, we focus on approaches for synthesizing structurally interesting new forms of polyoxovanadate species, such as hexavanadates, dodecavanadates, and octadecavanadates.
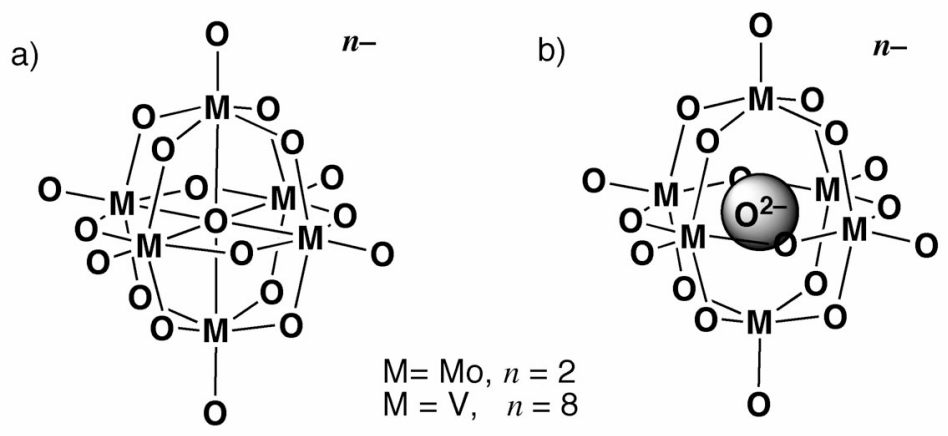

Fig. 1 Representation of hexametalate structures. (a) Schematic representation of hexametalate, (b) hypothetical representation of hexametalate as a spherical polyoxometalate with $\mathrm{O}^{2-}$ template anion.

\section{Synthetic approaches for hexavanadates}

While early attempts to synthesize hexavanadate $\left[\mathrm{V}_{6} \mathrm{O}_{19}\right]^{8-}$ ended in failure, strategies for the isolation of the hexavanadate framework were developed, which included protecting the bridging oxygens by organometallic groups [4], tripod alcohol ligands [5], or creating a coordination complex [6]. Although organometallic groups or tripod ligands almost certainly detached at some transient stage in solution, the free form of $\left[\mathrm{V}_{6} \mathrm{O}_{19}\right]^{8-}$ was never identified. Another strategy to stabilize the hexavanadate core is the reduction of the core. The reductive synthesis would result in a replacement of oxo-bridges to alkoxo-bridges, which decreases the negative charges on the core [7]. The highest oxidation state, $\mathrm{V}^{\mathrm{V}}$ hexavanadate, without bulky substituents on the surface of the core has been achieved by Hill et al. employing a simple methoxy group, and its solution properties were investigated by NMR spectroscopy and electrochemistry [8].

Since hexavanadate core itself was unknown and might be structurally unstable due to the high number of negative charges, we looked at the appropriate precursor. Due to the propensity for hydrolysis and isomerization, we were unable to isolate a satisfactorily pure form of the alkoxo-derivatives, and were forced to find an alternate synthesis. To avoid the hydrolysis of vanadium alkoxide, we employed alcoholysis of a 1D tetravanadate derivative.

Metavanadate species in the solid state is a polymer that is composed of a 1D chain of vertexsharing tetrahedrons of $\mathrm{VO}_{4}$ unit. This polymeric species can be degraded by hydrolysis in hot water to give metavanadate species, but cannot be degraded by alcoholysis because of $3 \mathrm{D}$ interactions between chains through counter cations. To make a polymer that is more susceptible to alcoholysis, we used the 
polymeric metavanadate with an organic cation [9]. In organic solvents, a cyclic tetravanadate $\left[\mathrm{V}_{4} \mathrm{O}_{12}\right]^{4-}$ is the typical species in acetonitrile [10]. By employing triphenyl phosphonium cation, the $3 \mathrm{D}$ network interaction between the chains can be avoided, which is a requirement for driving the alcoholysis reaction. The 1D tetravanadate 1 shown in Fig. 2 proved to be a successful precursor for the synthesis of alkoxo-derivatives of hexavanadate anion.

a)

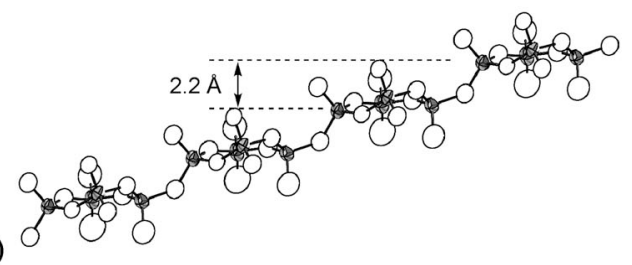

b)

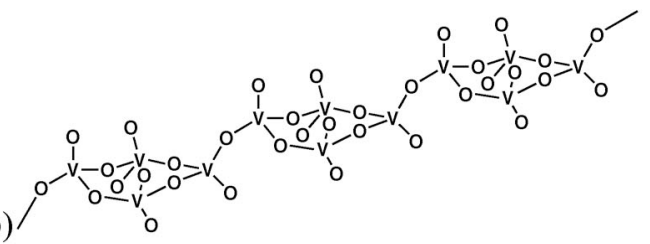

Fig. 2 (a) ORTEP view of $1 \mathrm{D}\left[\mathrm{V}_{4} \mathrm{O}_{11}\right]^{2-}, \mathbf{1} ; \mathrm{V}^{\mathrm{V}}$ and $\mathrm{O}$ atoms are represented by equatorial octant and hollow octant ellipsoids, respectively. (b) Schematic representation of $\mathbf{1}$ [9].

The four $\mathrm{V}$ atoms of $\mathbf{1}$ lie on the least-squares best plane within $0.21 \AA$. Each plane defined by the four cyclic tetravanadates forms a 1D chain ladder, and the interplane distance to the next nearest tetravanadate is approximately $2.2 \AA$. The individual chains are completely separated by the bulky organic cation, and no interaction between chains is observed. When compared with a discrete tetravanadate, $\left[\mathrm{V}_{4} \mathrm{O}_{12}\right]^{4-}$, compound $\mathbf{1}$ is more stable yet more reactive toward nucleophiles because of its fewer negative charges.

The alcoholysis of this stable compound is a handy method for constructing alkoxovanadates, and this route provides quick and easy access to hexamethoxohexavanadate, $\left[\mathrm{V}_{6} \mathrm{O}_{13}\left(\mathrm{OCH}_{3}\right)_{6}\right]^{2-}(\mathbf{2})$. The dissolution of $\mathbf{1}$ in methanol simply gives an orange solution, allowing crystal growth of hexamethoxohexavanadate, 2.

The conformation of the methoxy substituents was symmetrical, and the view from the pseudo three-fold axis is shown in Fig. 3a. The methoxy groups deviated from the layer of central oxygens by $0.2 \AA$ alternately up and down. A comparison of interlayer distances between complex 2 and other derivatives with hexavanadate cores is shown in Table 1 . The differences in the interlayer distances of $\mathrm{A}$ and B, which are defined in Fig. 3b, clearly show the distorted features of complex 2 . The other complexes show less distortion, and this reflects the negative charge compensations by organometallic cationic groups, increased number of methoxy group due to the reduction of the core, and chelate effects by the multidentate ligand, respectively.

a)

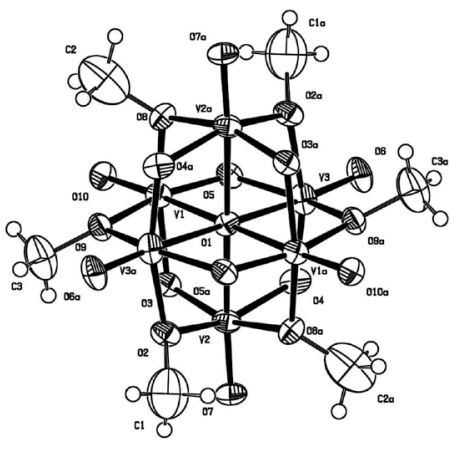

b)

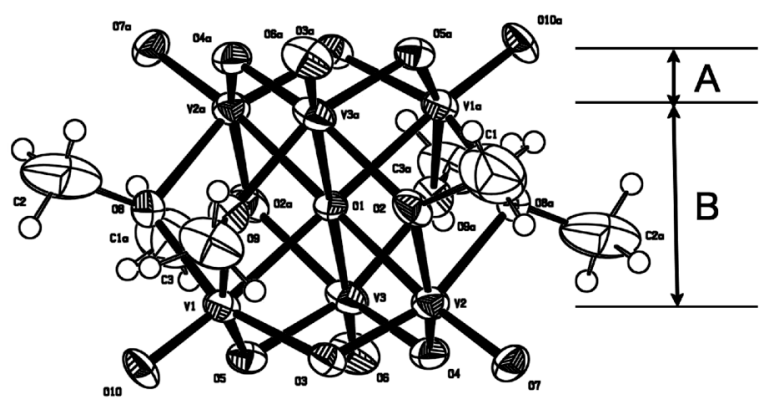

Fig. 3 ORTEP view of $\left[\mathrm{V}_{6} \mathrm{O}_{13}\left(\mathrm{OCH}_{3}\right)_{6}\right]^{2-}, 2$. (a) Top view from a pseudo 3-fold axis, (b) side view showing the alternate layer of $\mathrm{V}$ and $\mathrm{O}$ atoms in the close-packed layers. 
Table 1 Interlayer distances of hexavanadate core.

\begin{tabular}{lcc}
\hline Complex & $\mathrm{A}(\AA)^{\mathrm{a}}$ & $\mathrm{B}(\AA)^{\mathrm{a}}$ \\
\hline $\mathbf{2}$ & 0.79 & 2.78 \\
{$\left[\left(\mathrm{RhCp}^{*}\right)_{4} \mathrm{~V}_{6} \mathrm{O}_{19}\right]$} & 0.89 & 2.59 \\
{$\left[\mathrm{~V}_{6} \mathrm{O}_{7}\left(\mathrm{OCH}_{3}\right)_{12}\right]^{2-}$} & 0.92 & 2.55 \\
{$\left[\mathrm{~V}_{6} \mathrm{O}_{13}\left\{\left(\mathrm{OCH}_{2}\right)_{3} \mathrm{CCH}_{3}\right\}_{2}\right]^{2-}$} & 1.01 & 2.36 \\
\hline
\end{tabular}

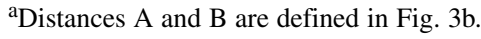

Although the ${ }^{51} \mathrm{~V}$ NMR spectrum of 2 shows a singlet at $-548 \mathrm{ppm}$, the methyl signals in the ${ }^{1} \mathrm{H}$ NMR spectrum exhibit multiple peaks between 4.2-4.7 ppm. The different chemical environments of the methyl signals may be attributed to the isomerization of the bridging methoxy groups on the core. Electrochemical studies show one quasi-reversible one-electron reduction wave ( $E=0.314 \mathrm{~V}$ vs. $\mathrm{Ag}^{+} / \mathrm{Ag}$ ) which is very close to the example of Hill's group [8].

\section{[V6 + V6] coupling reaction}

Hexametalate may be regarded as a spherical structure with an oxygen template at the center. In fact, the metal ions of the core do not lie at the center of the octahedron, but are always displaced substantially toward the exterior of the hexametalate structure leaving a space at the center. The metal-oxygen (center) distances are very long $(>2.2 \AA$ ) and may be regarded as ionic interactions. When we consider the core as a spherical cage with an oxo anionic template, the core itself may be converted into the open cage structure by the repulsion. By taking advantage of the reactive hexavanadate core of $\mathbf{2}$, which arose from the distorted hexavanadate framework, the coupling reaction of 2 was achieved, giving a [6+6] core of a bowl-type dodecavanadate.

Bowl-type dodecavanadates have always been observed with an accompanying template at the center of the cavity [11]. There are no empty dodecavanadates reported, and to isolate a template-free dodecavanadate, it is necessary to avoid polar solvents as possible templates. Using the bulky $t$-butyl alcohol with dichloromethane solvents enabled the successful conversion of $\mathbf{1}$ into the dodecavanadate, $\left[\mathrm{V}_{12} \mathrm{O}_{32}\right]^{4-}$, a bowl-type molecule. Interestingly, in our case, there was no template inside the cavity. Instead, the cavity was capped by a dichloromethane molecule through the chlorine atom. The position of the chlorine (Fig. 4) was $0.2 \AA$ up from the average plane of the eight V atoms at the entrance of the bowl. This may be regarded as the first empty dodecavanadate species isolated and may lead to structures that are capable of holding small negatively charged species inside the cavity.

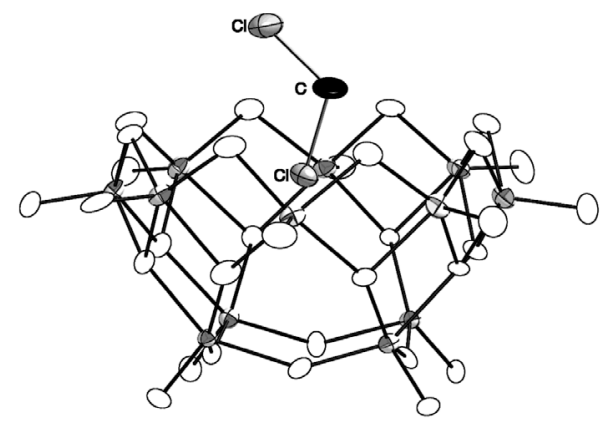

Fig. 4 ORTEP view of $\left[\mathrm{V}_{12} \mathrm{O}_{32}\right]^{4-} \cdot\left(\mathrm{CH}_{2} \mathrm{Cl}_{2}\right), 3$. $\mathrm{V}^{\mathrm{V}}$ and $\mathrm{O}$ atoms are represented by equatorial octant and hollow octant ellipsoids, respectively. Hydrogen atoms of dichloromethane are omitted. 


\section{Double-helical octadecavanadate in acetonitrile solution}

Self-assembled inorganic architectures such as helicates [12], artificial equivalents of double-stranded DNA molecules, have been investigated through the control of ligands and metal systems. Realization of such a helical polyoxovanadate may be potentially useful for bioinorganic applications. However, enantiopure polyoxometalates for which the rational synthesis of the metal oxide frameworks are much more difficult, are still in the infant stages [13]. Recent work in our laboratory has focused on reductive coupling methods for the controlled synthesis of reduced polyoxovanadates [14]. In the course of this study, we recently discovered the octadecavanadate, $\left[\mathrm{V}^{\mathrm{V}}{ }_{16} \mathrm{~V}^{\mathrm{IV}}{ }_{2} \mathrm{O}_{46}\left(\mathrm{NO}_{3}\right)\right]^{5-}(4)$, when an oxidation reaction of the reduced decavanadate, $\left[\mathrm{V}_{10} \mathrm{O}_{26}\right]^{4-}$ with $t$-butylhydroperoxide, was performed with the nitrate template anion in nitroethane [15]. The absolute structure of the chiral octadecavanadate was unambiguously assigned, and the crystals were optically resolved into enantiomers by spontaneous resolution. A nitrate anion was incorporated at the center of the spherical polyoxovanadate cage. The structure was a spherical polyoxovanadate composed of two ribbons of eight $\mathrm{VO}_{5}$ units bridging between two square-pyramidal $\mathrm{V}^{4+} \mathrm{O}_{5}$ units as shown in Fig. 5.

a)

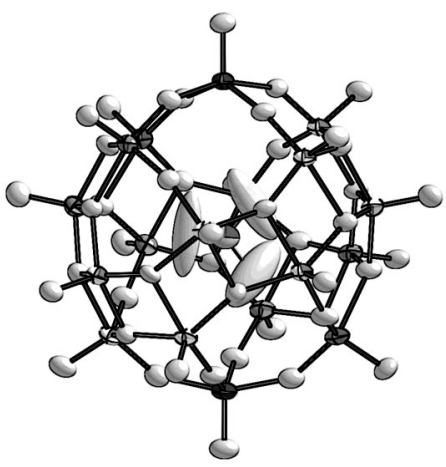

b)

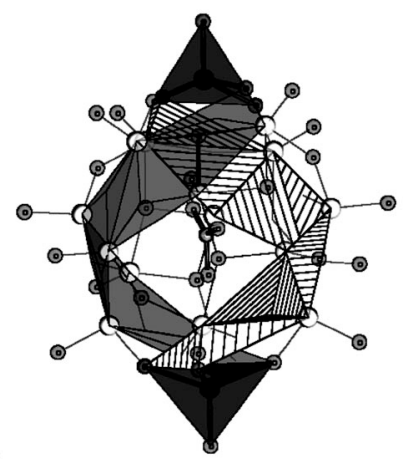

Fig. 5 (a) Thermal ellipsoid view of $\left[\mathrm{VV}_{16} \mathrm{~V}^{\mathrm{IV}}{ }_{2} \mathrm{O}_{46}\left(\mathrm{NO}_{3}\right)\right]^{5-}, 4 . \mathrm{V}^{\mathrm{V}}$ and $\mathrm{O}$ atoms are represented by equatorial octant and hollow octant ellipsoids, respectively. (b) Side view of $\mathbf{4}$ showing the double-stranded structure of the cluster. To emphasize the double-helical feature, two ribbons composed by edge sharing eight $\mathrm{V}^{\mathrm{V}} \mathrm{O}_{5}$ pyramidal units are illustrated as striped and gray ribbons between two $\mathrm{V}^{\mathrm{IV}}$ centers represented by dark pyramidal units at the top and bottom of 4 .

It is remarkable that the two V8 ribbons form helices themselves around a nitrate anion template and form a chiral molecule without any organic parts, i.e., no amino acids, no proteins, not even a $\mathrm{C}-\mathrm{C}$ bond. Instead, the framework is constructed with linkages of a $\mathrm{VO}_{5}$ pyramidal unit, consisting of a halfpitch helix of $\sim 11.0 \AA$ in diameter and a half-pitch length of $8 \AA$. This is the first polyoxovanadate with the framework of a double helix, and further investigations on its interactions with DNA will be interesting. First, however, the question of whether this species exists in solution must be answered. Although this compound is readily recrystallized and shows reversible waves in cyclic voltammetry without decomposition, an inorganic double-stranded molecule in solution with weak ionic interaction may be elusive. To address this question, we report the direct structural evidence by means of X-ray absorption near-edge spectroscopy (XANES) and extended X-ray absorption fine structure (EXAFS) spectroscopy through the comparison of the sample in solid state and in acetonitrile solution.

In V K-edge XANES spectra, a pre-edge peak appeared at $5.469 \mathrm{keV}$, and a rising edge was observed at 5.489 and $5.501 \mathrm{keV}$. The peak positions are within the range of reported $\mathrm{V}^{5+}$ and $\mathrm{V}^{4+}$ standard compounds [16]. The splitting of the rising edge indicates the presence of two kinds of vanadium 
coordination environments, and reflects the structure of complex $\mathbf{4}$ which has two kind of vanadium coordination spheres, one is $\mathrm{V}^{4+} \mathrm{O}_{5}$ and the other is $\mathrm{V}^{5+} \mathrm{O}_{5}$ coordination environments.

The V K-edge EXAFS oscillation signal in the range of 0-12 A shown in Fig. $6 \mathrm{~b}$ clearly demonstrates the match between the solid-state sample (solid line) and the solution sample (dotted line), supporting other evidence that the structure of the crystallographically determined structure is maintained even in acetonitrile solution.

a)

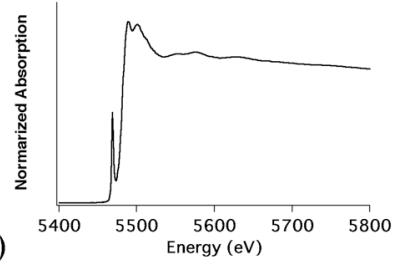

b)

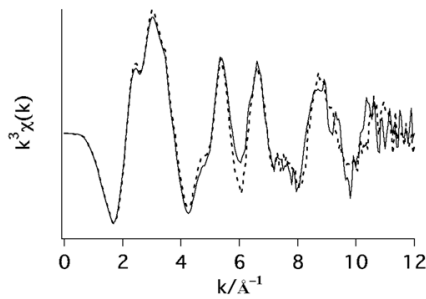

c)

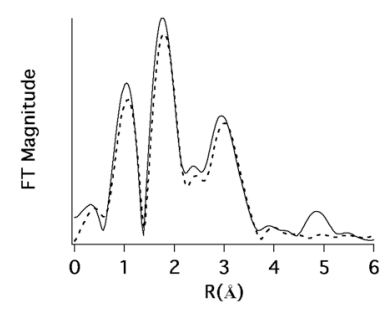

Fig. 6 (a) V K-edge XANES spectra in acetonitrile, (b) V K-edge EXAFS oscillations for the solid state (solid line), and in acetonitrile solution (dotted line), (c) experimental (solid line) and simulated (dotted line) FT of 4.

The FT of the EXAFS signal was simulated by using the programs FEFF and REX2000. The experimental and simulated spectra were in good agreement, and the V....V shortest distances (2.9-3.2 $\mathrm{A}$ ) observed in spherical 4 were in agreement with the EXAFS data. The slightly higher intensities of the FT peaks of the V $\cdots . \mathrm{V}$ shell radii are indicative of a spherical structure that has a number of close V $\cdots . \mathrm{V}$ distances due to the geometry. In conclusion, the chiral structure of $\mathbf{4}$ with a double helix of V8 ribbons is confirmed to exist even in solution, and is reminiscent of the discovery of the chirality of $\Lambda$ and $\Delta$ in coordination chemistry. This new all-inorganic helical complex may be of further interest in bioinorganic applications, especially when separation of the enantiomers becomes possible. We are currently investigating the possibility of optical resolution.

\section{CONCLUSIONS}

Our new route to synthesize a hexaalkoxohexavanadate is attractive because the 1D tetravanadate precursor $\mathbf{1}$ is very stable, gives hexamethoxohexavanadate by simply dissolving in methanol, and promotes a coupling reaction to afford an empty dodecavanadate species. Previous hexavanadate species included various types of ligands, but our case is close to a naked hexavanadate with symmetrically coordinated methoxy ligands. It should be possible in the near future to use the hexavanadate as a reaction intermediate in the development of various types of new polyoxovanadates. The structural confirmation of double-helical octadecavanadate both in solid and solution states is fascinating and future applications will be forthcoming.

It should be noted that the incorporation of these soluble oxide clusters into an infinite array of solid oxides should allow for their development in electronic devices. In other words, they can serve as molecular precursors for the design of new oxide devices.

\section{EXPERIMENTAL}

\section{Physical measurements}

XANES and EXAFS data were performed with the synchrotron beamline BL01B1 at SPring-8 (Himeji, Japan). The spectra for $\mathrm{V}-\mathrm{K}$ edges $(5.464 \mathrm{keV})$ were recorded in transmission mode at room temperature using a double-crystal $\mathrm{Si}(111)$ monochromator. X-rays were detected by two ion chambers, which 
were purged with a mixture of $70 \% \mathrm{He}$ and $30 \% \mathrm{~N}_{2}$ in $\mathrm{I} 0$ and $100 \% \mathrm{~N}_{2}$ in I1, respectively. The solid sample was finely ground, diluted with $\mathrm{BN}$, and pressed into a 1-mm-thick pellet. The liquid sample was sealed in a transparent plastic bag with approximate thickness through a hand-made cell.

The data analysis and handling were performed with the program package REX2000 (Rigaku). The EXAFS spectra were analyzed using the FEFF8 code of the University of Washington analysis programs for ab initio calculation of scattering paths [17].

\section{Synthesis of $\left(\mathrm{Ph}_{4} \mathrm{P}\right)_{2}\left[\mathrm{~V}_{4} \mathrm{O}_{11}\right], 1$}

The improved synthesis of the literature was shown here [9]. To a stirred aqueous solution $(20 \mathrm{ml})$ of $\mathrm{NaVO}_{3}(1.0 \mathrm{~g}, 8.2 \mathrm{mmol})$ was added dropwise a $0.1 \mathrm{M} \mathrm{HCl}$ solution $(40 \mathrm{ml})$. After addition of $\mathrm{Ph}_{4} \mathrm{PBr}$ $(1.72 \mathrm{~g}, 4.1 \mathrm{mmol})$, the solution was boiled at bubbling temperature with vigorous stirring on a hot plate for $20 \mathrm{~min}$, and then it was cooled to room temperature and filtered to obtain a light yellow powder, which was washed with water, then acetonitrile. Yield: $2.01 \mathrm{~g}(92 \%)$. This powder was recrystallized from aqueous ammonia solution to give crystals of $\mathbf{1}$. Elemental analysis calcd. for $\mathrm{C}_{48} \mathrm{H}_{40} \mathrm{O}_{11} \mathrm{~V}_{4} \mathrm{P}_{2}$ : C 54.46, H 3.81, V 19.25; found: C 54.28, H 3.73, V 19.16. IR ( $\left.\mathrm{cm}^{-1}\right)$ : 997(w), 975(m, sh), 944(m sh), 860(s, sh), 835(s, sh), 723(s), 683(s).

\section{Synthesis of $\left(\mathrm{Ph}_{4} \mathrm{P}\right)_{2}\left[\mathrm{~V}_{6} \mathrm{O}_{13}(\mathrm{OMe})_{6}\right], 2$}

Addition of 1 (1.06 g, $1.0 \mathrm{mmol})$ into $10 \mathrm{ml}$ of methanol solution produced a yellow solution. Addition of $60 \mathrm{ml}$ of ether caused a precipiate to form which was filtered to obtain an orange powder, then washed with ether. Yield: $640 \mathrm{mg}$. This powder was dissolved in $2.5 \mathrm{ml}$ of methanol and cooled overnight to give red-orange crystals of 2. Yield: $30 \mathrm{mg}(14 \%)$. Elemental analysis calcd. for $\mathrm{C}_{54} \mathrm{H}_{58} \mathrm{O}_{19} \mathrm{~V}_{6} \mathrm{P}_{2}$ : C 47.05, H 4.24; found: $\mathrm{C} 46.57, \mathrm{H} 4.43$. IR (cm $\left.{ }^{-1}\right)$ : 1034(m), 997(w, sh), 954(s sh), 762(m), 723(s, sh), 692(m), 667(m). ${ }^{51} \mathrm{~V}$ NMR $\left(\mathrm{CD}_{3} \mathrm{OD}, \mathrm{VOCl}_{3}\right): \delta-548(\mathrm{~s}) \mathrm{ppm}$. Crystal data depositions: 2: CCDC-698359.

\section{Synthesis of $\left(\mathrm{Ph}_{4} \mathrm{P}\right)_{4}\left[\mathrm{~V}_{12} \mathrm{O}_{32}\left(\mathrm{CH}_{2} \mathrm{Cl}_{2}\right)\right]$, 3}

$2(50 \mathrm{mg})$ was dissolved in a mixed solvent of dichloromethane $(3.0 \mathrm{ml})$ and tert-butanol $(1.0 \mathrm{ml})$ and refluxed overnight to give a brown solution. After addition of ether to the solution, the resulting brown powder was redissolved in dichloromethane to remove the insoluble material. $\mathrm{PPh}_{4} \mathrm{Br}(42 \mathrm{mg}, 0.1$ $\mathrm{mmol})$ and ether were added to the filtrate. After 1 day, brown crystals were collected. IR $\left(\mathrm{cm}^{-1}\right)$ : $993(2$, sh), 950(w, sh), 865(m), 829(m), 761(s, sh), 721(s sh), 688(s sh), 647(s sh). ${ }^{51} \mathrm{~V}$ NMR $\left(\mathrm{CD}_{3} \mathrm{NO}_{2}\right.$, $\left.\mathrm{VOCl}_{3}\right): \delta-589,-596,-605 \mathrm{ppm}$.

\section{ACKNOWLEDGMENTS}

The author thanks Tomoya Uruga (Japan Synchrotron Radiation Research Institute, JASRI) for support with XANES and EXAFS studies as well as for useful discussions.

\section{REFERENCES}

1. (a) D. Hou, K. S. Hagen, C. L. Hill. J. Am. Chem. Soc. 114, 5864 (1992); (b) T. Kurata, Y. Hayashi, A. Uehara, K. Isobe. Chem. Lett. 1040 (2003).

2. A. Müller, R. Sessoli, E. Krickemeyer, H. Boegge, J. Meyer, D. Gatteschi, L. Pardi, J. Westphal, K. Hovemeier, R. Rohlfing, J. Doering, F. Hellweg, C. Beugholt, M. Schmidtmann. Inorg. Chem. 36, 5239 (1997). 
3. (a) M. T. Pope. Heteropoly and Isopoly Oxometalate, Springer-Verlag, Berlin (1983); (b) J. P. Jolivet. Metal Oxide Chemistry and Synthesis, John Wiley, Chichester (2000).

4. (a) Y. Hayashi, Y. Ozawa, K. Isobe. Chem. Lett. 425 (1989); (b) Y. Hayashi, Y. Ozawa, K. Isobe. Inorg. Chem. 30, 1025 (1991).

5. (a) Q. Chen, D. P. Goshorn, C. P. Scholes, X. Tan, J. Zubieta. J. Am. Chem. Soc. 114, 4667 (1992);

(b) Q. Chen, J. Zubieta. Inorg. Chem. Acta 198-200, 95 (1992).

6. M. Piepenbrink, M. U. Triller, N. H. J. Gorman, B. Krebs. Angew. Chem., Int. Ed. 14, 2523 (2002).

7. (a) V. G. Kessler, G. A. Seisenbaeva. Inorg. Chem. Commun. 3, 203 (2000); (b) J. Spandl, C. Daniel, I. Brüdgam, H. Hartl. Angew. Chem., Int. Ed. 42, 1163 (2003); (c) C. Daniel, H. Hartl. J. Am. Chem. Soc. 127, 13978 (2005); (d) M. A. Augustyniak-Jablokow, C. Daniel, H. Hartl, J. Spandl, Y. V. Yablokov. Inorg. Chem. 47, 322 (2008); (e) C. Aronica, G. Chastanet, E. Zueva, S. A. Borshch, J. M. Clemente-Juan, D. Luneau. J. Am. Chem. Soc. 130, 2365 (2008).

8. D. Hou, G. Kim, K. S. Hagen, C. L. Hill. Inorg. Chem. Acta 211, 127 (1993).

9. S. Sharma, A. Ramanan, P. Y. Zavalij, M. S. Whittingham. Cryst. Eng. Commun. 4, 601 (2002).

10. (a) H. Nakano, T. Ozeki, A. Yagasaki. Inorg. Chem. 40, 1816 (2001); (b) H. Nakano, T. Ozeki, A. Yagasaki. Acta Crystallogr., Sect. C 58, m464 (2002); P. Roman, A. N. Luque, J. M. GutierrezZorrilla. Inorg. Chem. 32, 775 (1993).

11. (a) V. W. Day, W. G. Klemperer, O. M. Yaghi. J. Am. Chem. Soc. 111, 5959 (1989); (b) W. G. Klemperer, T. A. Marquart, O. M. Yaghi. Mater. Chem. Phys. 29, 97 (1991); (c) M.-M, Rohmer, J. Devemy, R. Wiest, M. Benard. J. Am. Chem. Soc. 118, 13007 (1996); (d) N. Kawanami, T. Ozeki, A. Yagasaki. J. Am. Chem. Soc. 122, 1239 (2000).

12. J.-M. Lehn. In Supramolecular Chemistry: Concepts and Perspectives, Chap. 9, VCH, Weinheim (1995).

13. (a) X. Fang, T. M. Anderson, Y. Hou, C. L. Hill. Chem. Commun. 40, 5044 (2005); (b) X. Fang, T. M. Anderson, C. L. Hill. Angew. Chem., Int. Ed. 44, 3540 (2005).

14. (a) Y. Hayashi, T. Shinguchi, T. Kurata, K. Isobe. In Vanadium: The Versatile Metal, K. Kustin, J. C. Pessoa, D. C. Crans (Eds.), Chap. 29, p. 408, Oxford University Press (2007); (b) Y. Hayashi, Y. Koyama, T. Shinguchi, K. Isobe. In Vanadium Biochemistry, M. A. Alves (Ed.), Chap. 2, p. 15, Research Signpost, Kerala, India (2007); (c) Y. Hayashi, N. Miyakoshi, T. Shinguchi, A. Uehara. Chem. Lett. 170 (2001).

15. Y. Koyama, Y. Hayashi, K. Isobe. Chem. Lett. 578 (2008).

16. Y. Izumi, F. Kiyotaki, N. Yagi, A.-M. Vlaicu, A. Nisawa, S. Fukushima, H. Yoshitake, Y. Iwasawa. J. Phys. Chem. B 109, 14891 (2005).

17. S. I. Zabinsky, J. J. Rehr, J. J. Ankudinov, R. C. Albers, M. J. Eller. Phys. Rev. B 52, 2995 (1995). 